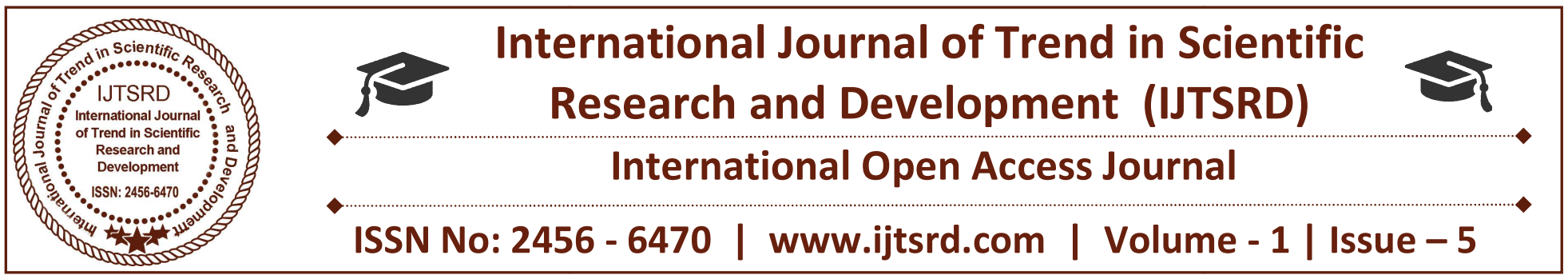

\title{
Study of Intermolecular Interactions through Freelength, and Internal Pressure of Ternary Liquid Mixture of Alcohol, Formic Acid and Tri-Ethyl Amines
}

\author{
P J Thakare \\ S SS K R Innani Mahavidyalay, \\ Karanja(Lad), Maharashtra, India
}

\author{
J B Thakare \\ S SS K R Innani Mahavidyalay, \\ Karanja(Lad), Maharashtra, India
}

\author{
N G Belsare \\ Vidyabharti Mahavidyalay, \\ Amravati, Maharashtra, India
}

\begin{abstract}
Ultrasonic velocities, Densities and Viscosities are measured for ternary liquid mixture of formic acid and tri-ethylamine (TEA) with ethanol. From this experimental data freelength, excess freelength, internal pressure and excess internal pressure have been calculated. The behaviour of mixture has been investigated at $303 \mathrm{~K}, 308 \mathrm{~K}$ and $313 \mathrm{~K}$ for frequency $2 \mathrm{Mz}$. These parameters have been discussed to throw light on intermolecular interactions between the components of ternary mixture.
\end{abstract}

Keywords: molecular interactions, hydrogen bonding, freelength, internal pressure, ternary liquid mixtures, TEA, carboxylic acids

\section{INTRODUCTION}

Waves of frequencies higher than $20 \mathrm{KHz}$ are called as ultrasonic waves. Their wavelengths are smaller than that of sound waves. Propagation of these ultrasonic waves in liquid and liquid mixtures helps us to examine the nature of intermolecular and intramolecular interaction in this system ${ }^{1}$.Carbonyl group is a functional group of many biologically important molecules such as protein, carboxylic acids and hormones. Carbonyl compounds contain polar carbonyl group in which electron rich oxygen can serves as electron donor. Whereas amines behave as bases since they contain nitrogen as the basic centre with lone pair of electrons. Thus donor-acceptor complexes may be formed between acids and amines ${ }^{2}$. In this work ultrasonic investigations are carried out to detect the intermolecular interactions in ternary liquid mixture of carboxylic acids and amines. Ultrasonic velocity measurements have been used to detect the nature of interactions between compounds. Density, viscosity and velocity values have been used to calculate freelength, internal pressure, excess freelength and excess internal pressure.

\section{THEORY}

The distance covered by sound wave between the surfaces of the neighbouring molecules is known as intermolecular free length. It enables us thepredictintermolecular attractions between the components in ternary mixture. Any change,the increase or decrease in free length indicates weakening and strengthening of intermolecular attraction. As the ultrasonic velocity increases due to the increase in concentration, the interaction free length has to decrease and vice-versa as it is related to ultrasonic velocity and density as ${ }^{3,4}$,

$$
\mathrm{L}_{\mathrm{f}}=\mathrm{K} / \mathrm{U} \cdot \rho^{1 / 2}
$$

The measurement of internal pressure is another important parameter in the study of thermodynamic 
properties of liquids. The internal pressure is the cohesive force and is a resultant of force of attraction and force of repulsion between the molecules. It also gives an idea of the solubility characteristics of the components in the solvent. The internal pressure, $\left(\pi_{\mathrm{i}}\right)$ can be calculated by using equation ${ }^{5}$;

$$
\pi_{\mathrm{i}}=\mathrm{bRT}[\mathrm{K \eta} / \mathrm{U}]^{1 / 2}\left[{ }^{\mathrm{p} 2 / 3} / \mathrm{M}^{7 / 6}\right]
$$

Where $\mathrm{K}$ is a dimensionless constant and is independent of temperature and nature of liquids. Its value is $4.281 \times 10^{9}$.

The Excess freelengthL $\mathrm{L}_{\mathrm{f}}^{\mathrm{E}}$ for the ternary mixture was calculated by using following relation,

$$
\mathrm{L}_{\mathrm{f}}^{\mathrm{E}}=\mathrm{L}_{\mathrm{fmix}}-\left(\mathrm{L}_{\mathrm{f} 1} \mathrm{f}_{1}+\mathrm{L}_{\mathrm{f2}} \mathrm{f}_{2}+\mathrm{L}_{\mathrm{f} 3} \mathrm{f}_{3}\right)
$$

The Excess internal pressure $\pi \mathrm{i}^{\mathrm{E}}$ for the ternary mixture was calculated by using following equation,

$\pi_{\mathrm{i}}^{\mathrm{E}}=\pi_{\text {imix }}-\left(\pi_{\mathrm{i} 1} \mathrm{f}_{1}+\pi_{\mathrm{i} 2} \mathrm{f}_{2}+\pi_{\mathrm{i} 3} \mathrm{f}_{3}\right)$

\section{EXPERIMENTAL WORK}

\section{OBSERVATION TABLE:}

\section{System- Alcohol + Tri-ethylamine + Formic Acid}

In the present work density was measured by using density bottle (corning made certified $10 \mathrm{ml}$ ). Stopper is used in order to avoid evaporation of chemicals. Weight of bottle was taken by monopan balance (model no. K15)supplied by K-Roy and Company, Varanasi. Its capacity is $100 \mathrm{gm}$ with sensitivity of $0.01 \mathrm{mg}$. For the measurement of viscosity Ostwald viscometer was used. During measurement prepared sample was poured in to the viscometer and the time taken by the liquid sample to fall down from higher mark to lower mark. The liquids used for the work were of BDH AR grade. For the present work the chemicals used viz. Tri-ethylamine(TEA), Ethyl alcohol and Formic acid were procured SD fine Mumbai and from E Merk chemicals Ltd India. Samples of different concentration were prepared by mixing the component liquids in volume proportion. Every time $28 \mathrm{ml}$ of mixture was prepared for measurement of density, viscosity and ultrasonic velocity. The volume of alcohol which is used as solvent is kept constant while that of other two was varied. In the present work ultrasonic velocity was measured by ultrasonic interferometer. A crystal controlled interferometer,model No. M8 15 supplied by Mittal enterprises, New Delhi, was used for determination of ultrasonic velocity. Measurements are made at frequency $2 \mathrm{MHz}$.

Temp. 303K

\begin{tabular}{|c|c|c|c|c|c|c|c|}
\hline $\begin{array}{c}\text { Mole } \\
\text { of Formic } \\
\text { acid }\end{array}$ & $\begin{array}{c}\text { Density } \\
\left(\mathrm{gm} / \mathrm{cm}^{3}\right)\end{array}$ & $\begin{array}{c}\text { Viscosity } \\
(\mathbf{c p})\end{array}$ & $\begin{array}{c}\text { Velocity } \\
(\mathbf{c m} / \mathbf{s})\end{array}$ & $\begin{array}{c}\text { Free- } \\
\text { length } \\
(\mathbf{c m})\end{array}$ & $\begin{array}{r}\text { Internal } \\
\text { pressure } \\
\left(\mathbf{d y n e} / \mathbf{c m}^{2}\right)\end{array}$ & $\begin{array}{c}\text { Excess } \\
\text { Free-length } \\
(\mathbf{c m})\end{array}$ & $\begin{array}{c}\text { Excess } \\
\text { Pressure } \\
\left(\mathbf{d y n e}^{2} \mathbf{c m}^{2}\right)\end{array}$ \\
\hline $\mathbf{0 . 0 0 0 0}$ & 0.9104 & 1.8136 & 130800 & $5.06 \mathrm{E}-09$ & $1.17 \mathrm{E}+11$ & $-2.73 \mathrm{E}-10$ & $5.42 \mathrm{E}+10$ \\
\hline $\mathbf{0 . 1 2 3 0}$ & 0.9675 & 2.1959 & 145920 & $4.40 \mathrm{E}-09$ & $1.30 \mathrm{E}+11$ & $-6.56 \mathrm{E}-10$ & $5.36 \mathrm{E}+10$ \\
\hline $\mathbf{0 . 2 2 9 4}$ & 0.9846 & 1.9290 & 142830 & $4.45 \mathrm{E}-09$ & $1.27 \mathrm{E}+11$ & $-3.60 \mathrm{E}-10$ & $3.90 \mathrm{E}+10$ \\
\hline $\mathbf{0 . 3 2 2 3}$ & 1.0027 & 1.6823 & 137550 & $4.58 \mathrm{E}-09$ & $1.25 \mathrm{E}+11$ & $-2.21 \mathrm{E}-11$ & $2.63 \mathrm{E}+10$ \\
\hline $\mathbf{0 . 4 0 4 2}$ & 1.0104 & 1.3997 & 131700 & $4.77 \mathrm{E}-09$ & $1.19 \mathrm{E}+11$ & $3.48 \mathrm{E}-10$ & $1.13 \mathrm{E}+10$ \\
\hline $\mathbf{0 . 4 7 6 9}$ & 1.0239 & 1.1973 & 126450 & $4.93 \mathrm{E}-09$ & $1.15 \mathrm{E}+11$ & $6.76 \mathrm{E}-10$ & $-7.94 \mathrm{E}+08$ \\
\hline $\mathbf{0 . 5 4 1 8}$ & 1.0365 & 1.0623 & 122100 & $5.08 \mathrm{E}-09$ & $1.13 \mathrm{E}+11$ & $9.67 \mathrm{E}-10$ & $-1.04 \mathrm{E}+10$ \\
\hline $\mathbf{0 . 6 0 0 2}$ & 1.0494 & 0.8552 & 119700 & $5.15 \mathrm{E}-09$ & $1.04 \mathrm{E}+11$ & $1.17 \mathrm{E}-09$ & $-2.53 \mathrm{E}+10$ \\
\hline
\end{tabular}

Table: 1 
International Journal of Trend in Scientific Research and Development (IJTSRD) ISSN: 2456-6470

\section{Temp. 308K}

\begin{tabular}{|c|c|c|c|c|c|c|c|}
\hline $\begin{array}{c}\text { Mole } \\
\text { Fraction } \\
\text { of Formic } \\
\text { acid }\end{array}$ & $\begin{array}{c}\text { Density } \\
\left(\mathbf{g m} / \mathbf{c m}^{3}\right.\end{array}$ & $\begin{array}{c}\text { Viscosit } \\
\mathbf{y}(\mathbf{c p})\end{array}$ & $\begin{array}{c}\text { Velocity } \\
(\mathrm{cm} / \mathrm{s})\end{array}$ & $\begin{array}{c}\text { Free- } \\
\text { length } \\
(\mathbf{c m})\end{array}$ & $\begin{array}{c}\text { Internal } \\
\text { pressure } \\
\left(\mathbf{d y n e} / \mathrm{cm}^{2}\right)\end{array}$ & $\begin{array}{c}\text { Excess } \\
\text { Free-length } \\
(\mathbf{c m})\end{array}$ & $\begin{array}{c}\text { Excess } \\
\text { Pressure } \\
\left(\mathbf{d y n e} / \mathbf{c m}^{2}\right)\end{array}$ \\
\hline $\mathbf{0 . 0 0 0 0}$ & 0.9122 & 1.5337 & 129000 & $5.16 \mathrm{E}-09$ & $1.11 \mathrm{E}+11$ & $-5.18 \mathrm{E}-10$ & $4.91 \mathrm{E}+10$ \\
\hline $\mathbf{0 . 1 2 3 2}$ & 0.9648 & 1.9535 & 145710 & $4.44 \mathrm{E}-09$ & $1.25 \mathrm{E}+11$ & $-9.09 \mathrm{E}-10$ & $5.17 \mathrm{E}+10$ \\
\hline $\mathbf{0 . 2 2 9 7}$ & 0.9807 & 1.6695 & 141510 & $4.54 \mathrm{E}-09$ & $1.21 \mathrm{E}+11$ & $-5.32 \mathrm{E}-10$ & $3.76 \mathrm{E}+10$ \\
\hline $\mathbf{0 . 3 2 2 7}$ & 0.9967 & 1.5045 & 135840 & $4.69 \mathrm{E}-09$ & $1.21 \mathrm{E}+11$ & $-1.33 \mathrm{E}-10$ & $2.86 \mathrm{E}+10$ \\
\hline $\mathbf{0 . 4 0 4 7}$ & 1.0072 & 1.2808 & 130740 & $4.85 \mathrm{E}-09$ & $1.16 \mathrm{E}+11$ & $2.42 \mathrm{E}-10$ & $1.64 \mathrm{E}+10$ \\
\hline $\mathbf{0 . 4 7 7 3}$ & 1.0172 & 1.1016 & 125520 & $5.02 \mathrm{E}-09$ & $1.12 \mathrm{E}+11$ & $6.12 \mathrm{E}-10$ & $5.70 \mathrm{E}+09$ \\
\hline $\mathbf{0 . 5 4 2 3}$ & 1.0305 & 0.9611 & 120840 & $5.18 \mathrm{E}-09$ & $1.09 \mathrm{E}+11$ & $9.45 \mathrm{E}-10$ & $-3.43 \mathrm{E}+09$ \\
\hline $\mathbf{0 . 6 0 0 6}$ & 1.0456 & 0.9110 & 118020 & $5.27 \mathrm{E}-09$ & $1.10 \mathrm{E}+11$ & $1.19 \mathrm{E}-09$ & $-8.18 \mathrm{E}+09$ \\
\hline
\end{tabular}

Table no. 2

\section{Temp. 313K}

\begin{tabular}{|c|c|c|c|c|c|c|c|}
\hline $\begin{array}{c}\text { Mole } \\
\text { of Formic } \\
\text { acid }\end{array}$ & $\begin{array}{c}\text { Density } \\
\left(\mathrm{gm} / \mathrm{cm}^{3}\right)\end{array}$ & $\begin{array}{c}\text { Viscosity } \\
(\mathbf{c p})\end{array}$ & $\begin{array}{c}\text { Velocity } \\
(\mathbf{c m} / \mathbf{s})\end{array}$ & $\begin{array}{c}\text { Free- } \\
\text { length } \\
(\mathbf{c m})\end{array}$ & $\begin{array}{c}\text { Internal } \\
\text { pressure } \\
\left(\mathbf{d y n e}_{\mathbf{c}}{ }^{2}\right)\end{array}$ & $\begin{array}{c}\text { Excess } \\
\text { Free-length } \\
(\mathbf{c m})\end{array}$ & $\begin{array}{c}\text { Excess } \\
\text { Pressure } \\
\left(\mathbf{d y n e}^{\mathbf{c}} \mathbf{c m}^{2}\right)\end{array}$ \\
\hline $\mathbf{0 . 0 0 0 0}$ & 0.9060 & 1.3674 & 126600 & $5.33 \mathrm{E}-09$ & $1.07 \mathrm{E}+11$ & $-5.65 \mathrm{E}-10$ & $4.52 \mathrm{E}+10$ \\
\hline $\mathbf{0 . 1 2 3 3}$ & 0.9622 & 1.7431 & 144090 & $4.54 \mathrm{E}-09$ & $1.20 \mathrm{E}+11$ & $-9.96 \mathrm{E}-10$ & $5.12 \mathrm{E}+10$ \\
\hline $\mathbf{0 . 2 2 9 8}$ & 0.9777 & 1.4730 & 139440 & $4.66 \mathrm{E}-09$ & $1.16 \mathrm{E}+11$ & $-5.75 \mathrm{E}-10$ & $4.02 \mathrm{E}+10$ \\
\hline $\mathbf{0 . 3 2 2 8}$ & 0.9934 & 1.2986 & 135210 & $4.76 \mathrm{E}-09$ & $1.14 \mathrm{E}+11$ & $-2.00 \mathrm{E}-10$ & $3.23 \mathrm{E}+10$ \\
\hline $\mathbf{0 . 4 0 4 7}$ & 1.0043 & 1.1169 & 129060 & $4.96 \mathrm{E}-09$ & $1.11 \mathrm{E}+11$ & $2.36 \mathrm{E}-10$ & $2.41 \mathrm{E}+10$ \\
\hline $\mathbf{0 . 4 7 7 4}$ & 1.0166 & 0.9585 & 123960 & $5.14 \mathrm{E}-09$ & $1.07 \mathrm{E}+11$ & $6.18 \mathrm{E}-10$ & $1.59 \mathrm{E}+10$ \\
\hline $\mathbf{0 . 5 4 2 3}$ & 1.0285 & 0.8103 & 114240 & $5.54 \mathrm{E}-09$ & $1.05 \mathrm{E}+11$ & $1.21 \mathrm{E}-09$ & $9.57 \mathrm{E}+09$ \\
\hline $\mathbf{0 . 6 0 0 6}$ & 1.0409 & 0.6691 & 126600 & $5.33 \mathrm{E}-09$ & $9.58 \mathrm{E}+10$ & $1.19 \mathrm{E}-09$ & $-3.02 \mathrm{E}+09$ \\
\hline
\end{tabular}

Table no.3 


\section{Graphs:}

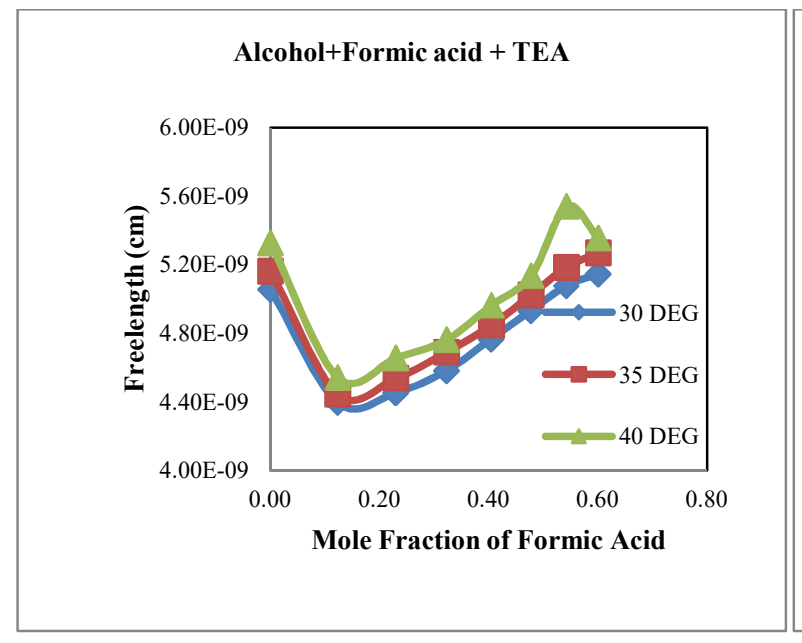

Fig. 1

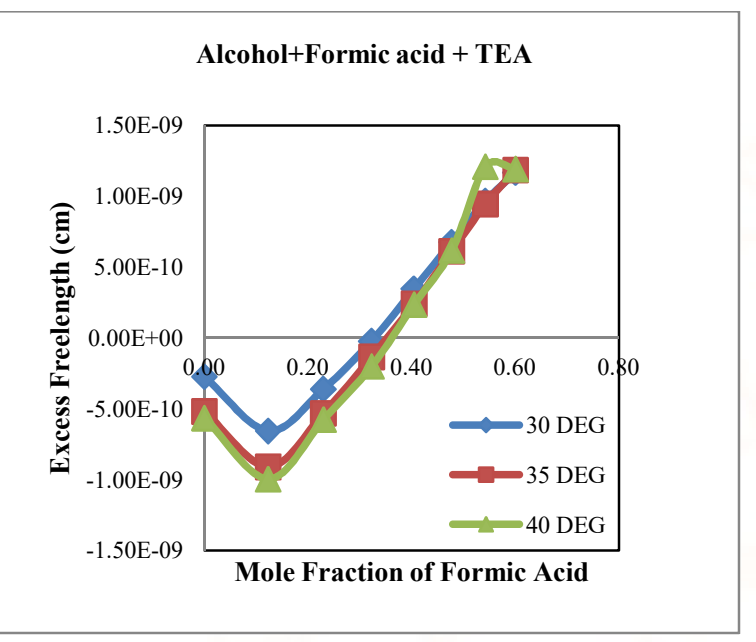

Fig. 2

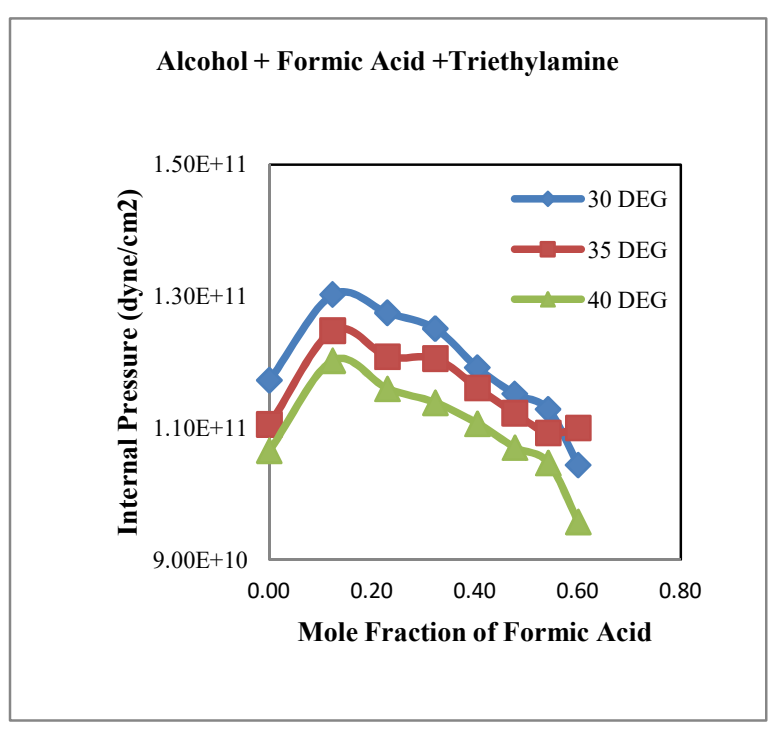

Fig. 3
Alcohol + Formic acid + Triethylammin e

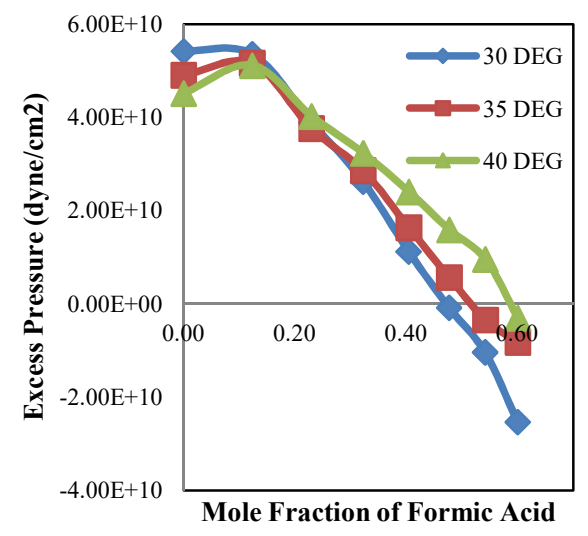

Fig. 4

\section{RESULTS AND DISCUSSION:}

Variation of freelength indicates variation in the molecular forces in the mixture which in turn depends on the experimental density as well as the temperatures of the mixture. The variation shows decreasing trend with the concentration of carboxylic acid become minimum and increases again. The nature of this variation of $\mathrm{L}_{\mathrm{f}}$ strongly depends on the size of molecules of the components. If the molecular size of components is equal then the curve for $\mathrm{L}_{\mathrm{f}}$ is expected to be linear ${ }^{6}$. In the present case the curves are nonlinear and it may probably be due to different sizes of molecules in the mixture. Decrease in $\mathrm{L}_{\mathrm{f}}$ also suggests the presence of strong interactions and the structural readjustment in the solutions leading to closer packing of molecules. This type of variation was also observed $\mathrm{by}^{7}{ }^{7}{ }^{8}$. In addition, the intermolecular freelength decides whether the intermolecular forces are attractive or repulsive. The $\mathrm{L}_{\mathrm{F}}$ values are foundto be higher at higher temperatures. The thermal agitations of the molecule are generallyresponsiblefor the increased values of $\mathrm{L}_{\mathrm{f}}$ at higher temperature.

The sign of excess freelength plays a vital role in assessing compactness due to molecular interaction through dipole-dipole interaction and hydrogen bonding.The values of excess freelength for the studied ternary system are summarized in table no. 1, 
2, 3. The excess free length values are positive on either ends where the mole fraction of either acid or amine is more. At intermediate concentrations the excess free length is negative. The negative values signify that the component molecules are closer in the mixture than the pure liquids. Inthe present investigation $L_{F}^{E}$ values are positive at ends showing dispersion and dipole-dipole forces between component liquid molecules. Similar conclusions were also drawn by Manoj Kumar Praharajet $\mathrm{al}^{9}$. The negative values at intermediate concentration predict complex formation between acids and amines by hydrogen bonding.

From Fig. 3 internal pressure increases at low mole fraction of carboxylic acid and high mole fraction of amines, becomesmaximum and decreases again at high mole fraction of carboxylic acid. This may be attributed to the possibility of hydrogen bonding or complex formation ${ }^{10}$.S P Poongothaiet $\mathrm{al}^{11}$ also found similar results. The rapid fall of $\pi_{\mathrm{i}}$ values with mole fraction of acid may be indication of weak interactions.

The present investigation shows that the values of excess internal pressure $\pi_{\mathrm{i}}^{\mathrm{E}}$ for system are negative at lower mole fraction of carboxylic acid and at the same time high mole fraction of amine and vice versa. When the mole fractions of both the component all near about equal the values of excess internal pressure is positive. The values of excess pressure are almost positive showing closer association. The negative values of $\pi_{\mathrm{i}}^{\mathrm{E}}$ indicate that only dispersion and dipolar forces are operating with complete absence of specific interaction $^{12}$. Similar type of results are also found by many authors ${ }^{13,14}$. In the present investigation the excess pressure is almost positive overall the concentration indicating strong specific interactions. Thus in the present case hydrogen bond complexation is mainly responsible for the positive values of excess pressure showing its dominance over the dipolar forces.

\section{CONCLUSION:}

All the experimental determinations of freelength, excess freelength, internal pressure and excess internal pressure predictstrong interactions between tri-ethylamine and formic acid at intermediate concentration .The presence of dispersion and dipoledipole forces between molecules of the mixture is also observed when either formic acid or TEA is in greater proportion. This may be due to dissociation of polymeric alcohol and dimeric formic acid on mixing.

\section{REFERENCES:}

1) K Rajathi, S J A Ali, A Rajendran, (2011), Ultrasonic study of molecular dynamics in some binary mixtures, Journal of Chemical and Pharmaceutical Reseach, vol. 3(5), 348-358.)

2) $\mathrm{S}$ Rajesh, $\mathrm{S}$ ChindambraVinayagam and $\mathrm{B} S$ Santhi, (2013), Ultrasonic studies on molecular interaction of benzaldehyde, cinnamaldehyde, 4methoxy bezaldehyde and diethylamine in nhexane solutions at $303 \mathrm{~K}$, Journal of Chemical and Pharmaceutical Research, vol. 5(1), 283-289.

3) Nomoto O, (1953), J Phys Soc Japan, Vol. 8, 553.

4) Nomoto O, (1953), J ChemPhys, vol. 21,950.

5) Schaff W, (1940), Z Phys, vol. 115,60.

6) S K Pradhan, S K Dash, L Moharana, B B Swain, (2012), Molecular interaction parameters of binary mixtures of diethyl ether and apolar solvents using ultrasonic probe, Indian Journal of Pure and Applied Physics, vol. 50, 161.

7) Ravichandran S, (2011), Res J ChemSci, vol. 1,12 .

8) J. B.Thakare,P.J.Thakare,Molecular interaction study through free volumes and internal pressures.(2012) Proceedings of National conference on Lasers and advanced materials 2930 may 2012,94-96

9) Manoj Kumar Praharaj, (2016), Molecular interactions in ternary liquid mixture involving toluene at different frequencies, Journal of chemical and pharmaceutical research, 8(1), 519524.

10) Ulagendran V, Kumar R, Jaykumar $S$ and Kannappan V, (2009) J MolLiq, vol. 148, 67.

11) $S P$ Pongothai and $S$ chidambravinayagam, (2017), Molecular interaction studies in ternary liquid mixtures containing O- Xylene at various temperatures using ultrasonic techniques.

12) Ciler $M$ and Kesanovil D, (1959), HydrogennBonding, 1, 1232.

13) $S$ Thirumaran, R Manthammal and $P$ Thenmozhi, (2012), ChemSci Trans, vol 1(3),674.

14) $S$ P Pongothai and $S$ chidambravinayagam, (2016), Ultrasonic studies on molecular interactions in ternary liquid mixtures at different temperatures, Journal of Chemical and Pharmaceutical Research, 8(11), 140-148. 